\title{
Pre-Operational Analysis of a Prototype Downdraft Gasifier Fueled by Bamboo
}

\author{
Julia Salovaara1,2, Hipólito Romero-Tehuitzil1, M. Consolación Medrano Vaca1, \\ Jorge Huacuz Villamar ${ }^{1}$ \\ ${ }^{1}$ Department of Renewable Energy, Electrical Research Institute, Cuernavaca, Morelos, México \\ ${ }^{2}$ Department of Chemistry and Bioengineering, Tampere University of Technology, Tampere, Finland \\ Email: $\underline{\text { hrt@iie.org.mx }}$
}

Received 9 March 2015; accepted 20 June 2015; published 23 June 2015

Copyright (C) 2015 by authors and Scientific Research Publishing Inc.

This work is licensed under the Creative Commons Attribution International License (CC BY). http://creativecommons.org/licenses/by/4.0/

(c) () Open Access

\begin{abstract}
Biomass gasification is a thermochemical conversion process that dates back to the 19th century. Nevertheless, designing and operating a gasifier system is not an easy task. Every biomass feedstock has different characteristics and the gasifier needs to be designed according to those qualities. Hence, many laboratory analyses on bamboo were carried out for this study. This study also concentrates on finding the best possible process variables for a bamboo fueled downdraft gasifier through a sensitivity analysis. A software program called Thermoflex was used for this purpose and the effect of gasifier temperature, air-fuel-ratio, moisture content of the fuel and temperature of pre-heated air on the syngas composition were simulated. The results show that bamboo is a decent gasification feedstock because of its low ash and sulfur content and satisfactory energy value. The simulations reveal that the best gas quality is obtained with the gasifier temperature between $700^{\circ} \mathrm{C}$ and $800^{\circ} \mathrm{C}, \mathrm{A} / \mathrm{F}$-ratio of $1.25-1.75$ and dry basis moisture content between $10 \%$ and $15 \%$.
\end{abstract}

\section{Keywords}

Biomass, Bamboo, Downdraft Gasifier, Thermoflex, Sensitivity Analysis

\section{Introduction}

The world is at turning point regarding energy issues. Especially in developing countries the demand for electricity is rising steeply because of growing population and energy-dependent technologies. This need of energy has been satisfied by fossil fuels but their reserves are finite and the price fluctuations are hard to foresee making their utilization more complicated and expensive in the future. Also the climate change is a concerning fact. 
Hence, there is an increasing need to look for alternative, clean and sustainable energy sources and to control the greenhouse emissions.

Biomass gasification is a thermochemical process where a limited amount of oxygen (air) reacts with feedstock in high-temperature producing synthesis gas. This gas can be fed into an internal combustion engine (ICE) or micro turbine to generate electricity. Many different biomasses can be gasified but this study concentrates on gasification of bamboo.

Gasification was a commercial process in England already in the 19th century but it has been very little investigated in Mexico, and this study is the first one to research gasification of bamboo in the country. In general studies on bamboo gasification in the open literature are rather limited. Some investigations carried out in Asia and Africa exist [1] [2] but most of the other studies of thermal conversion of bamboo discuss rather the production of activated carbon [3]-[5] or bio-oil [6]-[8], not the gasification.

To get an idea what kind of fuel bamboo is, its proximate and ultimate analysis together with calorific values was investigated and they are shown in the section of results. Because every biomass is different the gasifier should be designed according to the feedstock qualities. The qualities together with the desired engine output define not only the dimensions of the gasifier but also the process parameters. For this study a $50 \mathrm{~kW}$ gasifier was chosen, because it was calculated to be the most cost-efficient solution for the pilot project. Also the amount of available bamboo is limited but a $50 \mathrm{~kW}$ gasifier ensures that the plantations will not be over exploited.

In this study a series of sensitivity analysis is carried out by using a design and simulation software program called Thermoflex [9]. The objective was to study the effect of operating conditions of the gasifier on the syngas composition.

\section{Biomass Gasification}

The thermal conversion processes of biomass gasification consist of a few different phases that are normally modeled consecutive (one after another). Nevertheless, no sharp boundaries between the phases exist and they happen partly simultaneously. These phases are preheating and drying of the matter, pyrolysis, gasification and combustion [10]-[12].

\subsection{Drying}

Depending on the type of biomass the moisture content can rise up to 90\% (on dry basis) [12]. If moist feedstock is gasified or combusted, a lot of energy is used in drying. This amount of energy is not recoverable which causes a decrease of the heating value and a concern especially for energy applications. The moisture content of the feedstock in a downdraft gasifier should be between $10 \%-20 \%$ [12].

\subsection{Pyrolysis}

Pyrolysis is an essential and relatively fast reaction in a gasifier. It means thermal (=pyro) degradation (=lysis) of organic materials. They start to pyrolyze in elevated temperatures of $350^{\circ} \mathrm{C}-600^{\circ} \mathrm{C}$ forming a hydrogen-rich fraction and a carbon-rich residue called char [2] [12]. Pyrolysis is an endothermic reaction which means that it requires an external source of energy in order to occur.

\subsection{Combustion and Gasification}

The combustion and gasification reactions can be summarized in seven chemical equations [12] [13]:

$$
\begin{gathered}
\mathrm{C}+0.5 \mathrm{O}_{2}=\mathrm{CO} \\
\mathrm{C}+\mathrm{O}_{2}=\mathrm{CO}_{2} \\
\mathrm{C}+\mathrm{CO}_{2}=2 \mathrm{CO} \\
\mathrm{C}+\mathrm{H}_{2} \mathrm{O}=\mathrm{CO}+\mathrm{H}_{2} \\
\mathrm{C}+2 \mathrm{H}_{2}=\mathrm{CH}_{4} \\
\mathrm{CO}+\mathrm{H}_{2} \mathrm{O}=\mathrm{CO}_{2}+\mathrm{H}_{2}
\end{gathered}
$$




$$
\mathrm{CH}_{4}+\mathrm{H}_{2} \mathrm{O}=\mathrm{CO}+3 \mathrm{H}_{2} \text {. }
$$

The gas phase reactions (6) and (7) are important for the final gas quality. The Equation (6) has an influence on the $\mathrm{CO} / \mathrm{H}_{2}$ ratio whereas the Equation (7) increases the calorific value of the syngas [13]. However, Higman \& Van Der Burgt [10] state that the reactions (1) and (4) are the most essential in most gasification processes.

\section{Materials and Methods}

\subsection{Laboratory Analysis}

To get an idea what kind of fuel bamboo is, its proximate and ultimate analysis together with calorific values were investigated in the laboratories of Electrical Research Institute in Cuernavaca Mexico. To determine ash content, volatile matter and fixed carbon of bamboo, the following ASTM standard methods were used, respectively: D3174, D3175 and D3172. For determination of carbon, hydrogen and nitrogen content, D5373 was applied and for determination of sulfur the method D4239 was used. The amount of oxygen was obtained by balance calculations [14] [15].

To measure the higher calorific value (HCV) of bamboo in the laboratory the standard D5865 was utilized [14] [15]. The lower calorific value (LCV) was calculated based on the obtained HCV. The HCV can also be estimated through the following equation:

$$
\begin{aligned}
H C V= & 0.13491 \times X_{c}+1.1783 \times X_{H}+0.1005 \times X_{s} \\
& -0.0151 \times X_{N}-0.1034 \times X_{o}-0.0211 \times X_{\text {Ash }}
\end{aligned}
$$

where $X_{i}={ }^{-}$-\% of the substance $i$ on a dry basis [16]. In Equation (8) it can be seen that carbon, hydrogen and sulfur affect the HCV positively and nitrogen, oxygen and ash negatively.

\subsection{Location of the Project}

All the analyses and simulations were carried out at the Institute of Electrical Research in Cuernavaca Mexico. The gasification system discussed in this study is currently being built in the municipality of Huatusco, state of Veracruz.

The average altitude of the municipality is 1344 meters above the sea level but there are lower valleys and higher peaks as well. The annual rainfall is approximately $1825.5 \mathrm{~mm}$. Because of the high altitude the air pressure is lower than the standard value and because of the rain the air is usually very humid. The average temperature varies between 9 and 23 degrees centigrade but obviously the absolute values sink lower or rise higher [17]. These factors need to be considered because they affect the quality of the synthesis gas.

For this study only domestic bamboo, which grows in Huatusco, was investigated. The qualities of five different bamboo species were examined and the results are listed in Section 4.

\subsection{Thermoflex}

An engineering software program called Thermoflex [9] was used in this study. Four different variables were modified and their effect on the gas composition was examined. The variables are gasification temperature, the ER (air-fuel ratio), moisture content of the fuel and temperature of pre-heated air.

Thermoflex utilizes thermodynamic equilibrium models (heat balances) to carry out the simulations. It concerns only the reactions without letting the user define the gasifier geometry. The program does not specify if the "gasification temperature" is the temperature in the reduction zone, combustion zone, the gas exit temperature, an average of all of these or something else. The equilibrium is reached in an infinite time and that is why the software might give ideal yields as results. In practice, only a finite time is available for the reactions [12]. The reactions are highly dependent on reaction times, temperatures and the gasifier geometry which makes the use of Thermoflex a little bit clumsy. For example in the sensitivity analyses carried out for this study from six to seven different simulations had to be done in each case in order to model the behavior of the gasifier. The simulations are like still-photographs of the ongoing process. It is not possible to carry out a single continuous simulation. However, Thermoflex is a convenient and relatively simple program for studying the influence of fuel and process parameters and predicting the behavior of the entire system (especially if the components are already commercial). 


\subsection{Model Inputs}

The simulation model in Thermoflex was built using the components that exist in the library of the program. As seen in the process diagram presented in Figure 1 the simulated system includes a gasifier, gas conditioning equipment, a heat exchanger, and an ICE and every device is at the atmospheric pressure. The atmospheric pressure in Huatusco was measured to be 881 mbar (standard value 1014 mbar).

Thermoflex configures automatically some of the operational parameters. For example the air pressure of the gasifier was set at 1014 mbar (see Figure 1). The pressure of the fuel inlet and the pressure of the out coming ashes of the gasifier were established to be at the atmospheric pressure of the site (881 mbar).

The temperature of the gasifier and the air-fuel ratio $(\mathrm{A} / \mathrm{F})$ are each other's functions in Thermoflex meaning that if temperature is fixed by the user, the software adjusts the A/F-ratio according to the temperature. Then again if A/F-ratio is fixed, the temperature will vary. Both variables cannot be fixed at the same time. One of the most important factors defining the gasifier's operation is the equivalence ratio, ER, which is defined by using the $\mathrm{A} / \mathrm{F}-$ ratios as follows:

$$
\mathrm{ER}=\frac{\text { Actual Air }}{\text { Stoichiometric Air }}=\frac{\left(\frac{\mathrm{A}}{\mathrm{F}}\right)_{\text {Actual }}}{\left(\frac{\mathrm{A}}{\mathrm{F}}\right)_{\text {Stoichiometric }}}
$$

Stoichiometric means the amount of air that is needed for complete combustion of the fuel.

\subsection{Parameters Used in This Study}

The following inputs were used in the different simulations:

Gasification temperature:

- Ambient temperature $=\mathrm{T}_{\mathrm{amb}}=15^{\circ} \mathrm{C}$

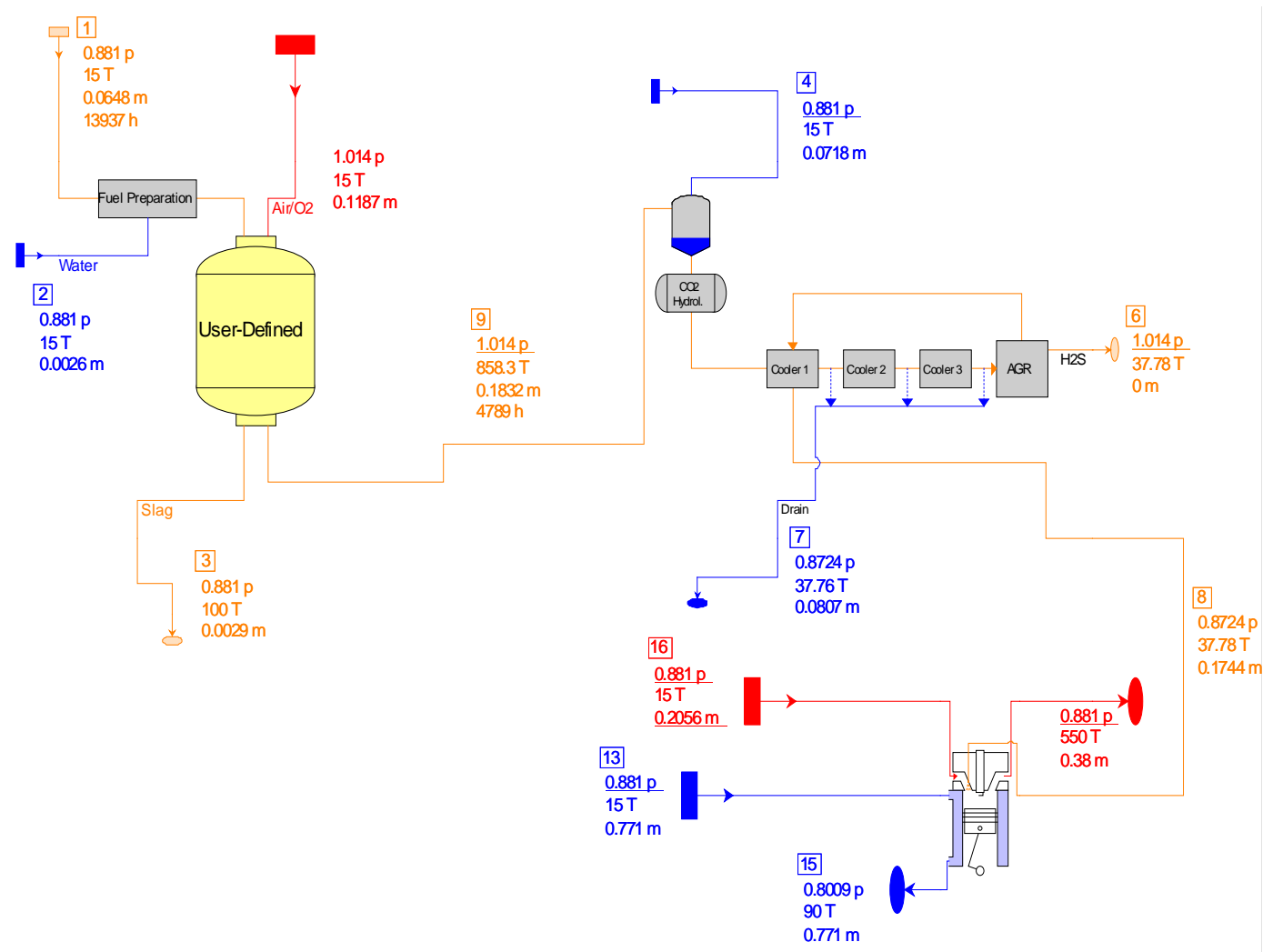

Figure 1. Thermoflex process flow chart of the gasification system. 
- Ambient pressure $=\mathrm{p}_{\mathrm{amb}}=881 \mathrm{mbar}$

- Relative humidity $=\Psi=60 \%$

- Moisture content of the fuel $=\mathrm{MC}_{\text {fuel }}=15 \%$

- Gasifier temperature $=\mathrm{T}_{\text {gasifier }}=500^{\circ} \mathrm{C} \cdots 1000^{\circ} \mathrm{C}$

- Air-fuel-ratio $=\mathrm{A} / \mathrm{F}=$ varies when temperature is changed

Air-fuel-ratio:

- $\mathrm{T}_{\mathrm{amb}}=15^{\circ} \mathrm{C}$

- $\mathrm{P}_{\mathrm{amb}}=881 \mathrm{mbar}$

- $\Psi=60 \%$

- $\mathrm{MC}_{\text {fuel }}=15 \%$

- $\mathrm{T}_{\text {gasifier }}=$ varies when $\mathrm{A} / \mathrm{F}$ is changed

- $\mathrm{A} / \mathrm{F}=0.5 \cdots 2.0$

Moisture Content of the fuel:

- $\mathrm{T}_{\mathrm{amb}}=15^{\circ} \mathrm{C}$

- $\mathrm{P}_{\mathrm{amb}}=881 \mathrm{mbar}$

- $\Psi=60 \%$

- $\mathrm{MC}_{\text {fuel }} \mathrm{l}=0 \% \cdots 25 \%$

- $\mathrm{T}_{\text {gasifier }}=800^{\circ} \mathrm{C}$

- $\mathrm{A} / \mathrm{F}=1.76$

Temperature of pre-heated air:

- $\mathrm{T}_{\mathrm{amb}}=15^{\circ} \mathrm{C}$

- $\mathrm{P}_{\mathrm{amb}}=881 \mathrm{mbar}$

- $\Psi=60 \%$

- $\mathrm{MC}_{\text {fuel }}=15 \%$

- $\mathrm{T}_{\text {gasifier }}=$ varies when the air is heated

- $\mathrm{A} / \mathrm{F}=1.76$

- $\mathrm{T}_{\text {air }}=50^{\circ} \mathrm{C} \cdots 600^{\circ} \mathrm{C}$

\section{Results and Discussion}

In this section the simulation results obtained in the software Thermoflex according to the chemical characteristics of bamboo are presented.

\subsection{Proximate Analysis}

An analysis for bamboo can be seen in Table 1. Also some reference values for wood, reed canary grass and coal are presented. Bamboo, as biomasses in general, includes a high amount of volatile matter (approximately $76-79 \mathrm{w}-\%$ ) as seen in Table 1. Typically the values vary between 70 and $86 \mathrm{w}-\%$ [20]. Because of these volatiles a major part of the biomass fuel is vaporized during the pyrolysis. Therefore, the amount of the volatile matter affects the thermal decomposition and combustion behavior of solid fuels [20]. For example Douglas fir of Table 1 would be expected to decompose faster than any of the bamboo species.

The volatiles may also turn into harmful tars depending on the process temperature and the gasifier design. That is another reason why a downdraft gasifier was selected for this project. It produces only $0.015-3.0 \mathrm{~g} / \mathrm{Nm}^{3}$ of tars [12] because it forces the pyrolyzed gases to flow through the hot grate where most of the tar-forming components decompose. Thus the synthesis gas is suitable to fuel an ICE.

Ashes can cause a lot of problems in gasifiers. The compounds may melt and agglomerate producing clinker and causing slagging. This slag has to be removed which increases the need for workforce, causes a break for operation and thus increases costs. The occurrence of slagging depends on the ash content of the fuel, the melting characteristics of the ash and the temperature profile of the gasifier. Usually slagging causes no troubles if the ash content of the fuel is lower than 5\% - 6\% [21]. Bamboo contains approximately $3 \%-5 \%$ of ash so slagging should not be a major problem but still the ash melting needs to be looked out for.

Fixed carbon is the solid part of the fuel that remains when all the volatile material, humidity and ash is driven off or distilled. It is an important parameter for gasification analysis because in most gasifiers the conversion of fixed carbon into gases determines the rate of gasification and its yield. It is also the slowest conversion reaction of the gasifier [12]. 
Table 1. The proximate analysis of bamboo, other biomasses and coal (dry-basis).

\begin{tabular}{cccc}
\hline Scientific Name & Volatile Matter & Ash & \multicolumn{2}{c}{ Fixed Carbon } \\
w-\% $\%$
\end{tabular}

Source for bamboo: [14]; Source for wood and coal: [18]; Source for grass: [19].

\subsection{Ultimate Analysis}

The ultimate analysis for bamboo is presented in Table 2.

Table 2 shows that wood and grass properties are fairly close to those of bamboo but coal is in its own category. The percentage of sulfur in bamboo is very low which is good because it does not produce that many acid components in gasification. In coal burning application corrosion might form a problem because of higher sulfur content of coal. Hydrogen in all of the fuels is within the same range but the amount of carbon varies. The difference in carbon causes the differences in the feedstock's calorific values as seen in the next section.

\subsection{Energy Content}

Higher calorific value (HCV) is a measure of energy content of biomass without any "free" water (=oven-dry basis). Still, the biomass contains chemically bound water and water that will arise as a result of combustion reactions. The HCV includes the latent heat of the water and that is why the result is higher [16].

The lower calorific value (LCV) is obtained when the latent heat of water is excluded from the results. The LCV is usually used when comparing results of different materials [16]. Both the HCVs and the LCVs of bamboo are listed in Table 3.

As seen in Equation (8) in Section 3.1 the carbon, hydrogen and sulfur content have a positive effect on the calorific value of the fuel whereas nitrogen, oxygen and ash lower the value. For example wood has more carbon and less ash than bamboo and hence the calorific value is higher. All biomasses include a high amount of oxygen as seen in Table 2. Coal then again has very little oxygen and a lot more carbon than biomasses. Therefore it has a high energy content (despite its high ash content).

\subsection{Sensitivity Analysis}

A sensitivity analysis was carried out by using a software program called Thermoflex. Different parameters were varied and the results are listed and discussed next.

Gasification temperature: because the A/F-ratio and the gasifier temperature are each other's functions in the program, two y-axes are illustrated in Figure 2: on the left the gas composition is presented and on the right the variation of the ER.

In Figure 2 a decline of $\mathrm{CH}_{4}$ and $\mathrm{CO}_{2}$ between $500^{\circ} \mathrm{C}-700^{\circ} \mathrm{C}$ can be observed. After that practically all the methane has been consumed and $\mathrm{CO}_{2}$ maintains roughly a constant level. All the other fractions of components increase of which $\mathrm{N}_{2}$ shows the steepest rise. This happens because of the increasing A/F-ratio (=meaning that the ER increases, too). At $1000^{\circ} \mathrm{C}$ six times more air is being fed into the gasifier than at $500^{\circ} \mathrm{C}$ so naturally the amount of $\mathrm{N}_{2}$ increases, too.

If the growing ER and its effects are forgotten, the volume fractions seem rational. The fraction of CO increases affecting positively the LCV of the gas. This increase is expected within higher temperature because 


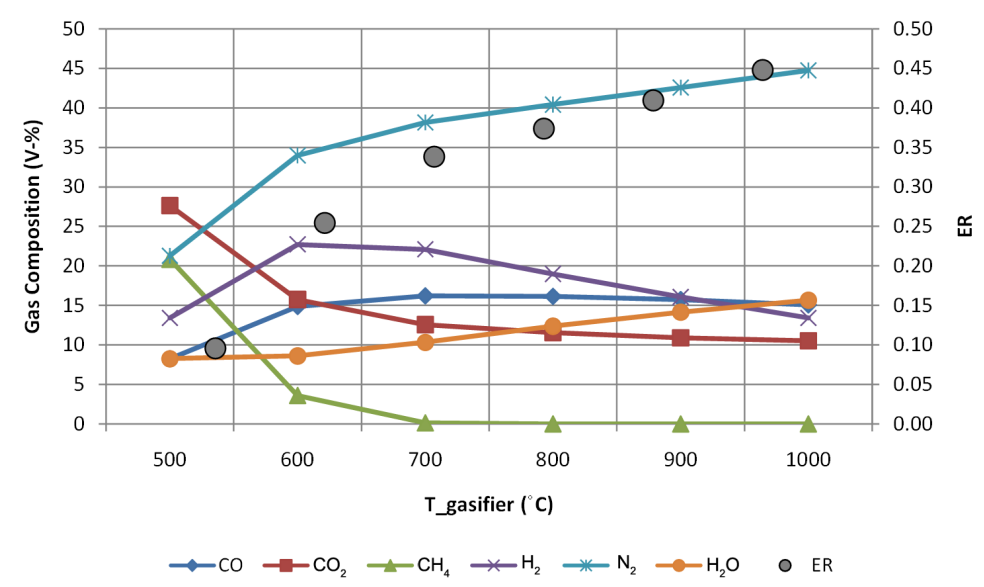

Figure 2. Variation of the syngas composition and the ER with gasifier temperature.

Table 2. The ultimate analysis of bamboo, other biomasses and coal (dry-basis).

\begin{tabular}{|c|c|c|c|c|c|}
\hline Scientific Name & $\begin{array}{c}\mathrm{C} \\
\mathrm{w}-\% \\
\end{array}$ & $\begin{array}{c}\mathrm{H} \\
\mathrm{w}-\%\end{array}$ & $\begin{array}{c}\mathrm{O} \\
\mathrm{w}-\%\end{array}$ & $\begin{array}{c}\mathrm{N} \\
\mathrm{w}-\%\end{array}$ & $\begin{array}{c}\mathrm{S} \\
\mathrm{W}-\%\end{array}$ \\
\hline Bambusa oldhamii Munro & 46.70 & 6.09 & 43.80 & $\mathrm{n} / \mathrm{d}$ & 0.05 \\
\hline Bambusa vulgarisVitata & 45.90 & 5.81 & 43.10 & $\mathrm{n} / \mathrm{d}$ & 0.05 \\
\hline Bambusa vulgaris Schrader & 46.00 & 5.95 & 43.10 & 0.15 & 0.05 \\
\hline Dendrocalamus strictus & 46.70 & 5.91 & 43.80 & 0.12 & 0.05 \\
\hline Dendrocalamus asper & 47.00 & 5.93 & 43.80 & $\mathrm{n} / \mathrm{d}$ & 0.05 \\
\hline Pseudotsuga menziesii (Wood) & 52.30 & 6.30 & 40.50 & 0.10 & 0.00 \\
\hline $\begin{array}{l}\text { Phalaris arundinacea } \\
\text { (Reed Canarygrass) }\end{array}$ & 44.60 & 5.55 & 40.11 & 0.00 & 0.22 \\
\hline Pittsburg Seam Coal & 75.50 & 5.00 & 4.90 & 1.20 & 3.10 \\
\hline
\end{tabular}

Source for bamboo: [14]; Source for wood and coal: [18]; Source for grass: [19].

Table 3. The calorific values of bamboo, other biomasses and coal (dry-basis).

\begin{tabular}{ccc}
\hline Scientific Name & HCV & LCV \\
Bambusa oldhamii Munro & MJ/kg & 17.20 \\
Bambusa vulgarisVitata & 18.50 & 16.91 \\
Bambusa vulgaris Schrader & 18.19 & 17.07 \\
Dendrocalamus strictus & 18.36 & 17.20 \\
Dendrocalamus asper & 18.50 & 16.91 \\
Wood & 18.19 & 19.50 \\
Phalaris arundinacea (Reed Canarygrass) & 21.00 & 16.83 \\
Black Coal & 18.49 & 28.70
\end{tabular}

Source for bamboo: [14] and [15]; Source for wood and coal [11]; Source for grass: [19].

Boudouard reaction (Equation (3)), $\mathrm{C}+\mathrm{CO}_{2} \leftrightarrow 2 \mathrm{CO}$, needs a certain amount of heat in order to occur. The reaction consumes $\mathrm{CO}_{2}$ and produces $\mathrm{CO}$ which explains their behavior in Figure 2.

The quantity of hydrogen first increases but then starts consuming itself after $700^{\circ} \mathrm{C}$. This affects negatively the LCV of the gas. The gas would have its highest heating value at $500^{\circ} \mathrm{C}$ because of the very high methane 
content but it has to be kept in mind that lignin (tars) needs $800^{\circ} \mathrm{C}-900^{\circ} \mathrm{C}$ of temperature to decompose [12]. That is why the methane is sacrificed to reach higher temperatures, accelerate other important reactions and get rid of harmful tars.

Considering all three factors (gas composition, temperature and the ER) it seems that the optimal values would be between $700^{\circ} \mathrm{C}-800^{\circ} \mathrm{C}$ when the ER is $0.34-0.37$ and the LCV of the gas $4320-3866 \mathrm{~kJ} / \mathrm{kg}$ at $25^{\circ} \mathrm{C}$.

A/F-ratio (the ER): the air-fuel-ratio (A/F) for the values $0.5-2.0$ was varied next. The two A/F-values (simulated and stoichiometric) are listed in Table 4 and the values of ER are calculated based on them. The ER is easier to compare with other literature values than the A/F-ratio, hence the conversion. The stoichiometric A/F means the air/fuel relation if the bamboo is completely combusted and it was obtained by balance calculations elaborated for this study. The ER was then calculated using the Equation (9).

As already explained, the gasification temperature and the A/F-ratio are dependent on each other in Thermoflex. That is why the Figure 2 and Figure 3 show relatively similar behavior. In Figure 3 the amounts of $\mathrm{CO}$ and $\mathrm{CO}_{2}$ are even when the $\mathrm{ER}=0.27$. After that the amount of $\mathrm{CO}_{2}$ decreases and the $\mathrm{CO}$ increases. Thus it seems that the gasifier should maintain the ER above 0.27 but stay below 0.38 . Above 0.38 the LCV of the gas is getting too low to be used in an engine-generator.

The moisture content: The third simulation was done by varying the moisture content of bamboo for the range $0 \%-25 \%$ as seen in Figure 4. The temperature was fixed at $800^{\circ} \mathrm{C}$ and the $\mathrm{A} / \mathrm{F}$-ratio was initially set to 1.76 but it started to lower slightly within the simulations (see declining values of $\mathrm{N}_{2}$ ). The software did not allow any higher moisture content to be simulated but according to literature [12] [22] 20\% is roughly the recommended limit for downdraft gasifiers so no further simulations are needed.

According to Figure 4 the ideal moisture content would be $0 \%$. However, this is not very practical because bamboo would need heavy drying to evaporate all the humidity it contains when it is fresh (up to 45\%) and that

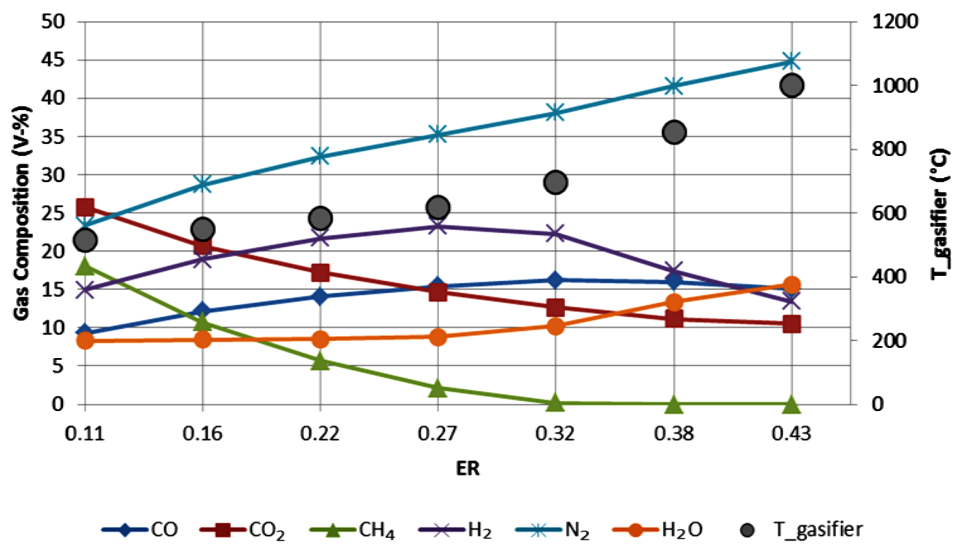

Figure 3. Variation of the syngas composition and the gasifier temperature with the ER.

Table 4. The air-fuel ratios and the calculated ER.

\begin{tabular}{ccc}
\hline $\mathrm{A} / \mathrm{F}$ (simulated) & $\mathrm{A} / \mathrm{F}$ (calculated) & ER \\
0.50 & 4.64 & 0.11 \\
0.75 & 4.64 & 0.16 \\
1.00 & 4.64 & 0.22 \\
1.25 & 4.64 & 0.11 \\
1.50 & 4.64 & 0.16 \\
1.75 & 4.64 & 0.22 \\
2.00 & 4.64 & 0.27 \\
\hline
\end{tabular}


would be energy and time consuming. A small amount of water is also needed as steam to react with volatiles and char and to take part in the water-gas shift reaction (Equation (4)) that produces hydrogen. Thus $0 \%$ is not convenient for the process. With reasonable effort the moisture content can be reduced to $10 \%-15 \%$ which is considered as a suitable amount of humidity in the fuel according to the sensitivity analysis and the literature. Thus $15 \%$ will be considered a satisfactory value.

Temperature of pre-heated air: the last simulation is done with a slightly different system. A heat exchanger is added into the system to utilize the hot exhaust gases of the ICE in order to pre-heat the air that is fed into the gasifier. Normally the air is at ambient temperature but now it is heated from $50^{\circ} \mathrm{C}$ up to $500^{\circ} \mathrm{C}$. It can be observed in Figure 5 that the composition of the gas hardly changes. A moderate increase in $\mathrm{CO}$ and a decrease in $\mathrm{CO}_{2}$ can be seen but the effect on the LCV is minimal. The temperature inside the gasifier rises within the air temperature. When trying to increase the air temperature to $600^{\circ} \mathrm{C}$, the software only let it rise up to $547.2^{\circ} \mathrm{C}$. At this point the gasifier temperature was already at $1073.1^{\circ} \mathrm{C}$ and the simulation did not run any further. $1000^{\circ} \mathrm{C}$ $1100^{\circ} \mathrm{C}$ might be a maximum limit for the temperature set by the software.

Although there are no big changes in the gas com-position according to Figure 5 there might be other advantages that could be obtained through pre-heating. When the gasifier is ignited, it takes a certain time before the process becomes steady. The temperature needs to rise so that the bamboo gets dried, all the essential reactions occur and tars are decomposed. The pre-heated air could speed up these processes and help to establish the process in shorter time. This would be beneficial for the equipment if the amount of tars could be decreased. The system could also achieve better overall system efficiencies when heat is recycled, not wasted. However, according to Figure 5 no recommended range for temperatures can be given. The effect of pre-heated air should

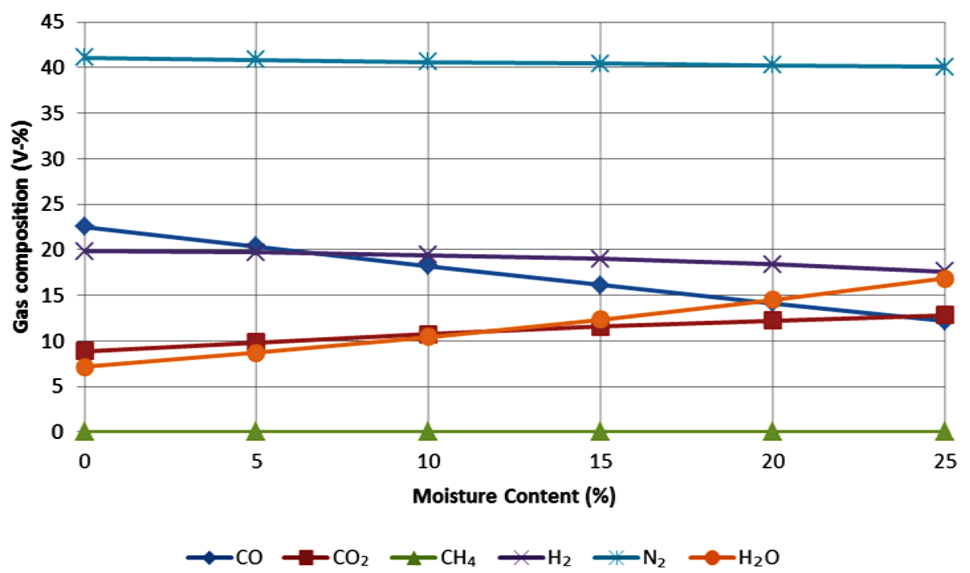

Figure 4. Variation of the syngas composition with the moisture content of bamboo.

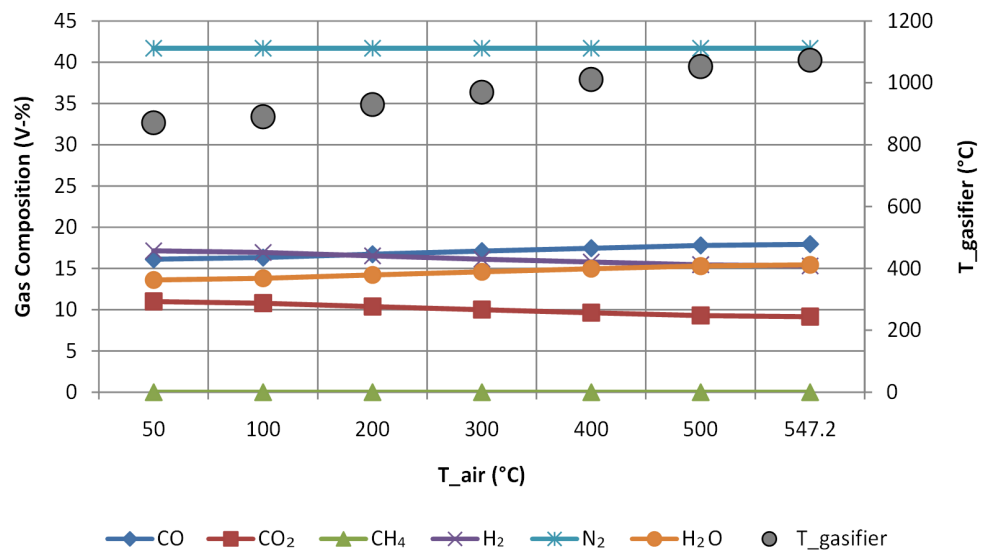

Figure 5. Variation of the syngas composition and gasifier temperature with the air temperature. 
be investigated using different software or observing the process in practice.

\section{Conclusions}

Bamboo in general seems to be a satisfying feed-stock for a downdraft gasifier because of its acceptable heating value, low ash content and low sulfur content. According to this study Bambusa oldhamii Munro and Dendrocalamus strictus seem to have the best qualities for gasification.

Finding the optimal parameters and obtaining good quality synthesis gas are challenging tasks because of the many affecting variables. According to Thermoflex simulations, the following parameters should be applied for the process:

$$
\begin{aligned}
& -\mathrm{MC}_{\text {fuel }}=10 \%-15 \% \\
& -\mathrm{T}_{\text {gasifier }}=700^{\circ} \mathrm{C}-800^{\circ} \mathrm{C} \\
& \text { - } \mathrm{A} / \mathrm{F}=1.25-1.75(\mathrm{ER}=0.27-0.38)
\end{aligned}
$$

This would set the lower calorific value of the gas approximately between 3647 and $5046 \mathrm{~kJ} / \mathrm{kg}$ at $25^{\circ} \mathrm{C}$. Beside the optimal process parameters discussed in this study, the Thermoflex simulations also helped to estimate the needed mass flows for bamboo and air so that enough gas could be produced to generate a $50 \mathrm{~kW}$ power. The future investigation should concentrate on real experiments on the field in order to validate the simulated results.

\section{Acknowledgements}

The authors would like thank the Sustainable Energy Fund of SENER-CONACYT (Project 152364, Trust 2138) for funding this project. They also thank the Ministry of Foreign Affairs of Mexico (Secretaría de Relaciones Exteriores), Tampere University of Technology and International Centre for Mobility (CIMO) who gave a grant for the Master Thesis of J. Salovaara. Special thanks are also given to the whole department of Renewable Energy-IIE.

\section{References}

[1] Ganesh, A. (2003) Bamboo Characterization for Thermochemical Conversion and Feasibility Study of Bamboo Based Gasification and Charcoal Making. Energy Systems Engineering of Indian Institute of Technology, Mumbai.

[2] de Rosbo, G.K. and de Bussy, J. (2012) Electrical Valorization of Bamboo in Africa. Enea Consulting, Paris.

[3] Choy, K.K.H., Barford, J.P. and McKay, G. (2005) Production of Activated Carbon from Bamboo Scaffolding WasteProcess Design, Evaluation and Sensitivity Analysis. Chemical Engineering Journal, 109, 147-165. http://dx.doi.org/10.1016/j.cej.2005.02.030

[4] Ip, A.W.M., Barford, J.P. and McKay, G. (2008) Production and Comparison of High Surface Area Bamboo Derived Active Carbons. Bioresource Technology, 99, 8909-8916. http://dx.doi.org/10.1016/j.biortech.2008.04.076

[5] Lo, S.-F., Wang, S.-Y., Tsai, M.-J. and Lin, L.-D. (2011) Adsorption Capacity and Removal Efficiency of Heavy Metal Ions by Moso and Ma Bamboo Activated Carbons. Chemical Engineering Research and Design, 90, 1397-1406. http://dx.doi.org/10.1016/j.cherd.2011.11.020

[6] Jiang, Z., Liu, Z., Fei, B., Cai, Z., Yu, Y. and Liu, X. (2012) The Pyrolysis Characteristics of Moso Bamboo. Journal of Analytical and Applied Pyrolysis, 94, 48-52. http://dx.doi.org/10.1016/j.jaap.2011.10.010

[7] Krzesińska, M. and Zachariasz, J. (2007) The Effect of Pyrolysis Temperature on the Physical Properties of Monolithic Carbons Derived from Solid Iron Bamboo. Journal of Analytical and Applied Pyrolysis, 80, 209-215. http://dx.doi.org/10.1016/j.jaap.2007.02.009

[8] Lou, R., Wu, S.-B. and Lv, G.-J. (2010) Effect of Conditions on Fast Pyrolysis of Bamboo Lignin. Journal of Analytical and Applied Pyrolysis, 89, 191-196. http://dx.doi.org/10.1016/j.jaap.2010.08.007

[9] Thermoflow, Section Thermoflex, Site-272-IIE.

[10] Higman, C. and Van Der Burgt, M. (2008) Gasification. 2nd Edition, Elsevier, UK.

[11] Raiko, R., Saastamoinen, J., Hupa, M. and Kurki-Suonio, I. (2002) Poltto ja Palaminen. 2nd Improved Edition, Gummerus, Jyväskylä.

[12] Basu, P. (2013) Biomass Gasification, Pyrolysis and Torrefaction: Practical Design and Theory. 2nd Edition, Academic Press, Amsterdam.

[13] Kristiansen, A. (1996) Understanding Coal Gasification. IEA Coal Research, London. 
[14] Instituto de Investigaciones Eléctricas, Laboratorio de Análisis de Combustibles, Gerencia de Procesos Térmicos (2012) Resultados del Análisis de Muestras de Bambú (Technical Report-Results of the Bamboo Sample AnalysesUnpublished). Proyecto 152364, Fideicomiso 2138, Fondo Sectorial CONACYT-Secretaría de Energía, Sustentabilidad Energética, IIE/44/14297/LAC/001/2012, Cuernavaca, Morelos, México.

[15] Instituto de Investigaciones Eléctricas, Laboratorio de Análisis de Combustibles, Gerencia de Procesos Térmicos (2012) Resultados del Análisis de Muestras de Bambú (Technical Report-Results of the Bamboo Sample AnalysesUnpublished). Proyecto 152364, Fideicomiso 2138, Fondo Sectorial CONACYT-Secretaría de Energía, Sustentabilidad Energética, IIE/44/11427/LAC/08/2012, Cuernavaca, Morelos, México.

[16] Rosillo-Calle, F., De Groot, P., Hemstock, S.L. and Woods, J. (2007) Biomass Assessment Handbook. Earthscan, London.

[17] The Government of Huatusco (2014) The Official Web Page of the Municipality of Huatusco, Veracruz. Historia del Municipio. http://www.huatusco.gob.mx/municipio/historia-del-municipio

[18] Reed, T.B. and Das, A. (1998) Handbook of Biomass Downdraft Gasifier Engine Systems. 2nd Edition, Superintendent of Documents, US Government Printing Office, Washington DC. http://dx.doi.org/10.2172/5206099

[19] Alakangas, E. (2000) Suomessa käytettävien polttoaineiden ominaisuuksia (Properties of Fuels Used in Finland). Valtion Tieteellinen Tutkimuskeskus (VTT) - Technical Research Centre of Finland, Espoo, Research Notes 2045.

[20] Van Loo, S. and Koppejan, J. (2008) The Handbook of Biomass Combustion and Co-Firing. Earthscan, London.

[21] FAO, Food and Agriculture Organization of the United Nations (1986) Wood Gas as Engine Fuel. Forestry Paper 72 , Mechanical Wood Products Branch, Forest Industries Division, FAO Forestry Department, Rome.

[22] Reed, T.B. and Gaur, S. (2001) A Survey of Biomass Gasification-Gasifier Projects and Manufacturers around the World. 2nd Edition, the National Renewable Energy Laboratory and the Biomass Energy Foundation, Inc., Colorado. 